\title{
Single-fiber Electromyography Examination in Patients Treated with Botulinum Toxin
}

\author{
Botulinum Toksin Tedavisi Alan Hastalarda Tek-lif Elektromiyografi Íncelemesi
}

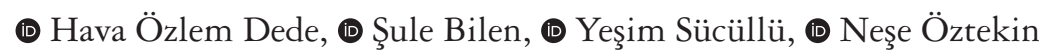 \\ Ankara Numune Training and Research Hospital, Clinic of Clinical Neurophysiology, Ankara, Turkey
}

\begin{abstract}
Objective: The aim of this study is to evaluate the neuromuscular junction functions of toxin-treated and non-administered muscles in patients who received botulinum toxin therapy.

Materials and Methods: Patients treated with botulinum toxin in our hospital's movement disorders outpatient clinic were examined in this study. With a $25 \mathrm{~mm}$ concentric needle and a lower cut filter $1 \mathrm{kHz}$, the average and the individual jitter values were recorded during the voluntary muscle contraction in the frontalis and extensor digitorum (ED) muscles. The relation between the demographic characteristics of the patients, dose of botulinum toxin, the duration of treatment, and the jitter values was researched.

Results: Including 14 patients with hemifacial spasm (HFS) and seven patients with cervical dystonia (SD), 21 patients treated with botulinum toxin (female/ male: 12/9) were examined. The mean age was $52.19 \pm 10.2$ years; there was no difference between the disease groups in terms of age ( $\mathrm{p}=0.714)$. The mean followup time was $3.2 \pm 1.3$ years; there was no difference between the disease groups in terms of follow-up time $(\mathrm{p}=0.188)$. The average jitter value of toxin injected to frontalis muscle in the HFS group was 55.6 \pm 10.6 microns, and the average high jitter value was $8.4 \pm 3.1$. The average jitter value of ED muscle without toxin injection was $23.5 \pm 3.2 \mu \mathrm{s}$ and no individual high jitter was detected. In the SD group, the average jitter values in the frontalis and ED muscles were $22.7 \pm 2.8$ and $27 \pm 1.7 \mu \mathrm{s}$, respectively. The individual high jitter value was 42 microns only in one patient. However, the only individual high jitter value detected in one patient was not considered pathologic.
\end{abstract}

Conclusion: In patients treated with botulinum toxin, neuromuscular junction defects were not detected in the muscles in which the toxin was not injected directly.

Keywords: Single-fibre EMG, botulinum toxin, neuromuscular junction, hemifacial spasm, cervical dystonia

Öz

Amaç: Bu çalışmanın amacı botulinum toksin tedavisi almış hastalarda toksin uygulanmı̧̧ ve uygulanmamış kaslarda nöromusküler kavşak işlevlerini değerlendirmektir.

Gereç ve Yöntem: Hastanemiz hareket hastalıkları polikliniğinde botulinum toksini tedavisi uygulanmış hastalar çalışmaya alındı. Frontalis ve ekstensor digitorum (ED) kaslarında istemli kası sırasında $25 \mathrm{~mm}$ konsantrik iğne ile alt kesim filtresi $1 \mathrm{kHz}$ olacak şekilde yirmişer tek lif benzeri potansiyel çiftinin ortalama ve bireysel jitter değerleri kaydedildi. Hastaların demografik özellikleri, uygulanan botulinum toksin dozları, tedavi süreleri ve jitter değerleri arasındaki ilişki incelendi.

Bulgular: Botulinum toksin tedavisi uygulanmış 14 hemifasiyal spazm (HFS), 7 servikal distoni (SD) olmak üzere 21 hasta (kadın/erkek: 12/9) incelemeye alındı. Ortalama yaş $52,19 \pm 10,2$ idi ve hastalık grupları arasında farklılık göstermiyordu ( $\mathrm{p}=0,714)$. Ortalama takip süresi $3,2 \pm 1,3$ yıldı, hastalık grupları arasında fark yoktu $(\mathrm{p}=0,188)$. HFS grubunda toksin uygulaması yapılmış frontalis kasından elde edilen ortalama jitter değeri 55,6 $6 \pm 10,6$ mikrosan, bireysel yüksek jitter sayısı ortalama 8,4 $\pm 3,1$ iken; toksin uygulaması yapılmamış ED kasında ortalama jitter 23,5 $\pm 3,2 \mu$ s idi ve bireysel yüksek jitter saptanmadı. SD grubunda botulinum toksini uygulanmamış frontalis ve ED kaslarında sırasıyla ortalama jitter $22,7 \pm 2,8$ ve $27 \pm 1,7 \mu$ s idi. Bireysel yüksek jitter bir hastada ED kasında 42 mikrosan olarak saptandi. Ancak saptanan tek bireysel yüksek jitter değeri patolojik olarak kabul edilmedi.

Sonuç: Çalışmamızda botulinum toksin tedavisi uygulanmış hastalarda toksinin doğrudan uygulanmadığı kaslarda nöromusküler kavşak işlev kusuru saptanmamiştır.

Anahtar Kelimeler: Tek-lif EMG, botulinum toksin, nöromusküler kavşak, hemifasiyal spazm, servikal distoni

Address for Correspondence/Yazışma Adresi: Hava Özlem Dede MD, Ankara Numune Training and Research Hospital, Clinic of Clinical Neurophysiology, Ankara, Turkey Phone: +90 3125526000 E-mail: havaozlemdede@hotmail.com ORCID: orcid.org/0000-0002-9900-2932

Received/Geliş Tarihi: 08.07.2019 Accepted/Kabul Tarihi: 31.03 .2020

${ }^{\circ}$ Copyright 2020 by Turkish Neurological Society

Turkish Journal of Neurology published by Galenos Publishing House. 


\section{Introduction}

Botulinum toxin disrupts nerve conduction by inhibiting the release of acetylcholine at the presynaptic terminal at the neuromuscular junction (1). Botulinum toxin type A (BtxA) received international approval for treatment of blepharospasm and strabismus in 1989, for symptomatic treatment of cervical dystonia (SD) in 2000, and cosmetic use in 2002 (2,3). Many adverse effects have been reported since its introduction. Rapidly self-limiting adverse effects can be listed as pain, edema, erythema, itching, hyperesthesia, and headache. Adverse effects associated with the spread of the toxin include dysphagia associated with its spread to neighboring areas, and fatigue, rash, cold-like symptoms, and pseudobotulism associated with its systemic spread. Findings of pseudobotulism are asthenia, ptosis, weakness, dysphagia, dysarthria, and diplopia (4). Flu-like symptoms due to systemic spread were reported at a frequency of $1.7-20 \%$ (5). More severe adverse effects, such as pseudobotulism or botulismus, have been reported fairly rarely. In patients treated with botulinum toxin, there are different opinions on the distant effects of the toxin when there are no clinical systemic adverse effects (4). There are studies that report a widespread defect in neuromuscular junction even when no botulismus is clinically observed $(6,7,8)$. In contrast, studies have shown that there may be no significant defects in neuromuscular junction functions in patients without clinical muscle weakness (4).

Botulinum toxin binds irreversibly to the presynaptic site within an average of 2 weeks, resulting in a clinical effect. The clinical effect of the toxin is eliminated within 3-6 months by regeneration of acetylcholine vesicles (9).

The most easily applicable, precise and reliable way of evaluating neuromuscular junction functions in striated muscle is single-fiber electromyography (EMG) using a concentric needle $(10,11,12)$. Single-fiber EMG is used in the diagnosis of foodrelated or iatrogenic botulismus, as well as in the diagnosis of other neuromuscular diseases (12).

The aim of our study was to evaluate the functions of neuromuscular junctions in muscles that were injected botulinum toxin and in muscles that were not injected botulinum toxin after the expected duration of effect of botulinum toxin passed in patients who received botulinum toxin therapy.

\section{Materials and Methods}

\section{Patient Selection}

Patients with hemifacial spasm (HFS) and SD treated with onaBtxA in our hospital's movement disorders and botulinum toxin applications outpatient clinic between January 2019 and March 2019 were included.

Patients with known polyneuropathy syndrome, cervical radiculopathy, diabetes mellitus, hypothyroidism, those who were diagnosed as having chronic obstructive pulmonary, had peripheral facial paralysis in their history, patients aged over 65 years, those with known bleeding diathesis, and those who received anticoagulant therapy were excluded.

Patients who received BtxA treatment for at least 1 year were examined on the same day following the last treatment session.

\section{Botulinum Toxin Application}

Every $100 \mathrm{U}$ onaBtxA content was diluted with $2.0 \mathrm{ml}$ of saline containing $0.9 \% \mathrm{NaCl}$ solution. Its concentration was set as $5 \mathrm{U} / 0.1 \mathrm{ml}$. The drug was administered within the first 15 minutes following dilution. Injections to the facial area were performed with a 30 gauge needle tip and $1 \mathrm{ml}$ injectors.

Muscles injected in patients with hemifacial spasm: orbicularis oculi (to preseptal and pretarsal regions), zygomaticus major, risorius, mentalis, levator labii superior alaa nasi, frontalis, and glabellar muscles. Into each area, 2.5-5 U BtxA was injected. A half dose was also administered to the opposite side and compared with the affected side.

For the treatment of SD, BtxA was injected to hyperactive muscles using 26 gauge, $50 \mathrm{~mm}$-long needles accompanied by the Intronix model 8008 myoguide system ${ }^{\text {TM }}$ EMG device. Muscles injected: sternocloidomastoid, semispinalis capitis, splenius capitis, levator scapula, trapezius, and scalenus. The choice of muscles was made under the guidance of an EMG device for each patient.

\section{Single-fiber EMG Examination}

Twenty single-fiber potential pairs were recorded from right frontalis and extensor digitorum (ED) muscles in all patients using $25 \mathrm{~mm}(30 \mathrm{G}$ ) concentric needles and $1 \mathrm{kHz}$ lower cut filter, with a Synergy 2-channel EMG device during voluntary muscle contraction. Individual and average jitter values were examined. The upper limit of normal individual and mean jitter were considered as 28 and $38 \mu$ s in the frontalis muscle and 30 and 43 $\mu$ s in ED muscle, respectively (13). Individual examinations were considered pathologic when the high individual jitter number detected was $\geq 2$ or when the average jitter value was high while the individual high jitter number was 1 .

\section{Statistical Analysis}

Statistical analysis was performed using the SPSS 21 package program. The chi-square test and student's t-test were used for comparisons in groups with normal distribution. A p value $<0.05$ was accepted statistically significant. The Mann-Whitney U test was used in groups without normal distribution. Individual high jitter numbers, average jitter values, and doses of BtxA administered were compared between muscles injected and muscles that were not injected in all individuals according to the disease groups. Multiple linear regression analysis was performed while investigating factors affecting mean jitter value in disease groups.

Prior to the study, written informed consent was obtained from all patients. This study was approved by the Ankara City Hospital's Ethics Committee 1 (number: E-19-002).

\section{Results}

In our study, 21 patients were evaluated, including 14 patients with HFS and seven patients with SD. In total, there were 12 female and nine male patients. The mean age was $52.19 \pm 10.2$ years (Table $1)$. The patients had been receiving BtxA treatment for a mean of $3.2 \pm 1.3$ years. There were no patients who reported any adverse effects of systemic spread during this time. The period from the previous BtxA application session to the time of examination was $4.3 \pm 1.9$ (minimum 3-maximum 12) months.

In the HFS group, the mean jitter was $55.6 \pm 10.6 \mu \mathrm{s}$, the mean individual high jitter percentage was $40.71 \pm 15.54 \%$, the number of neuromuscular type blocks was $1.69 \pm 0.63$ (minimum 1 -maximum 3 ) in the frontalis muscle with toxin injection. The 


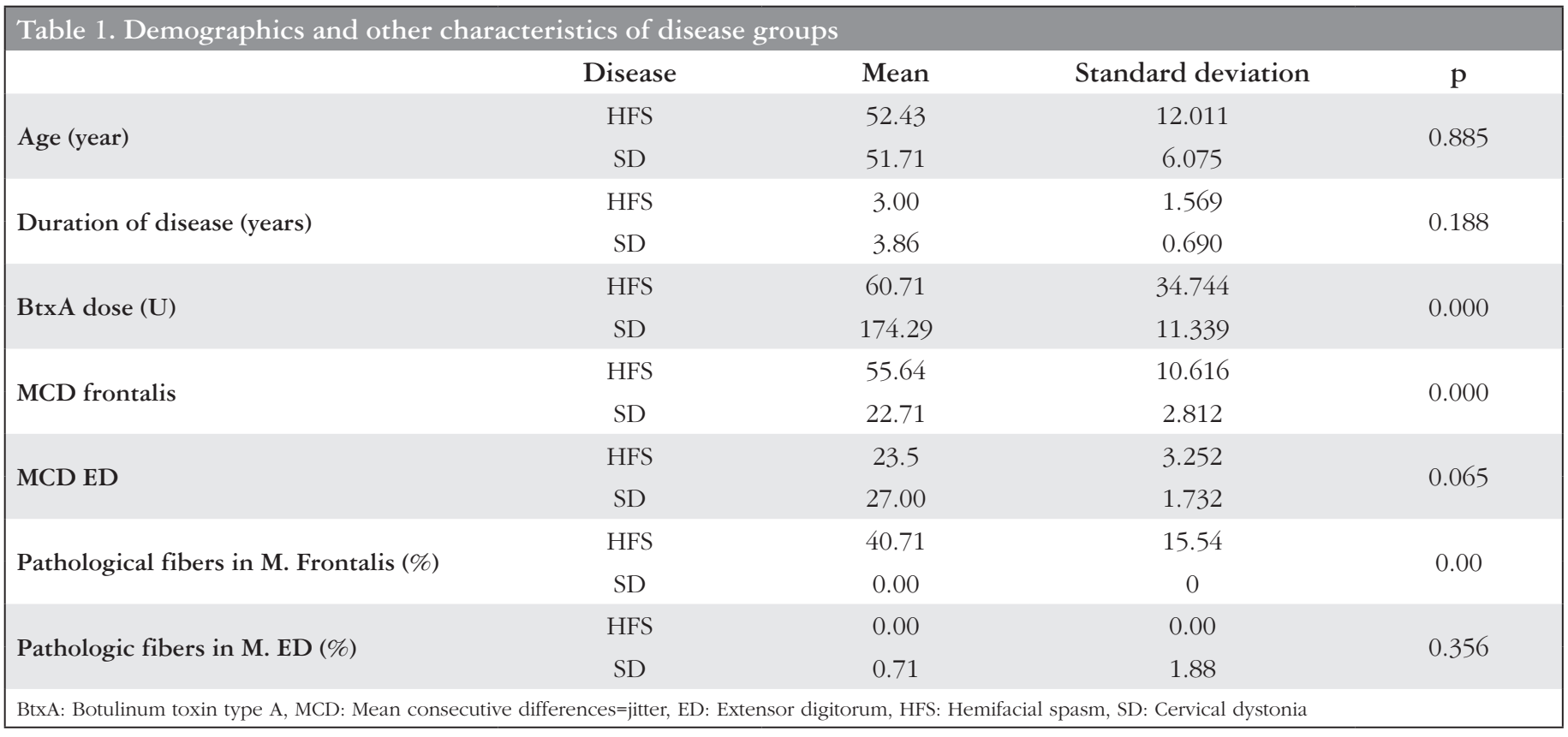

mean jitter was $23.5 \pm 3.2 \mu \mathrm{s}$ in the ED muscle without toxin injection. Individual high jitter was not detected.

The factors affecting the mean jitter value in the frontalis and ED muscles in the HFS group were examined and there was no correlation between the mean jitter value and age $(p=0.75 ; p=0.1)$, the time of injection of the previous BtxA ( $\mathrm{p}=0.36 ; \mathrm{p}=0.69)$, toxin dose $(p=0.41 ; p=0.79)$, and duration of illness $(p=0.94 ; p=0.96)$.

In the SD group, the mean jitter was $22.7 \pm 2.8 \mu$ s in the frontalis muscle without toxin injection and individual high jitter was not detected. The mean jitter was $27 \pm 1.7 \mu$ s in the ED muscle and individual high jitter ( $42 \mu \mathrm{s})$ was detected in one patient. When the factors affecting the mean jitter value in the frontalis and ED muscles were examined, no statistically significant correlation was found between the mean jitter value and age $(p=0.44 ; p=0.7)$, the time of injection of the previous BtxA $(\mathrm{p}=0.16 ; \mathrm{p}=0.78)$, toxin dose $(p=0.85 ; p=0.92)$, and disease duration $(p=0.999 ; p=0.999)$.

\section{Discussion}

In our study, neuromuscular junction functions were found to be significantly impaired in the muscles treated with BtxA. However, neuromuscular junction functions were found to be normal in muscles that were not administered BtxA. In patients with SD, a higher dose of the toxin than in patients with HFS did not cause systemic adverse effects.

BtxA is an effective treatment method frequently preferred for symptomatic treatment of dystonia and spasticity (14). There is inhibition of acetylcholine release at the neuromuscular junction under the influence of the toxin. The immature synapse, newly formed by axonal sprouting, is responsible for elongation in the jitter value (15). There are studies showing that the effect of toxin can be widespread (8). The path of spread is not clearly defined. Anterograde and retrograde transport, spread by blood and lymphatic route $(16,17)$, and secondary immune response are theories that have been put forward for spread (5). Although the toxin's therapeutic effect is short-term and temporary, permanent dysfunction of the neuromuscular junction suggests that the toxin may cause widespread functional defects in the chronic process. However, BtxA administration has rarely been reported to cause widespread weakness and this adverse effect is temporary (4). When pseudobotulism and widespread botulism occur, intensive care requirement of patients is rare $(18,19)$. The incidence of pseudobotulism has been reported as 1.4 in 1000 applications (4).

It is reported that the effect of BtxA on the neuromuscular junction begins on average in 14 days. The duration of action of treatment is expected to be 3-6 months (9). In our study, we aimed to investigate the residual effect of BtxA on the neuromuscular junction after the expected duration of action. For this reason, in order to evaluate the functions of the neuromuscular junction in the period after the end of treatment effect in patients, the examination was conducted in the session in which BtxA treatment should be repeated.

Neuromuscular junction functions in distant muscles following administration of BtxA have been studied since the 1980s. There are different views on this issue. In recent studies, neuromuscular junction defects has been reported in distant muscles in which the toxin is not directly injected in patients with widespread systemic adverse effects and weakness following BtxA administration $(4,5)$. On the other hand, assessments were found to be normal in the majority of patients who did not report systemic weakness (4). There was no significant difference in terms of jitter measurements between patients with widespread, nonunique fatigue symptoms and patients with no symptoms after botulinum toxin administration (4). In our study, there were no patients with adverse effects of systemic weakness. In patients with no signs of systemic spread, such as widespread weakness, we found normal neuromuscular junction functions in muscles that were not directly exposed to the toxin.

Earlier studies found high jitter at a low firing rate using a stimulated single-fiber method in the ED muscle without toxin injection following high-dose BtxA treatment $(7,8)$. The patients 
examined in these studies did not report widespread weakness. However, the use of stimulated single-fiber EMG as an evaluation method, which results in high jitter at slow stimulation frequency, constitutes methodologic differences. We and other researchers who have recently investigated this subject have performed singlefiber EMG during voluntary muscle contraction $(4,20,21)$. Our results may be different because of the methodologic differences. Ruet et al. (4) suggested that the use of botulinum toxin A with the onaBtxA formula, which was created in 1997, in the recent period might account for the difference between the old studies and recent studies.

There are studies showing that jitter values increase compared with their individual averages after BtxA treatment, but do not exceed normal limits $(15,21)$. It is stated that the most significant increase in jitter is observed on the $14^{\text {th }}$ day after injection, and this increase in jitter decreases afterwards (21). In those studies using prospective examination method which have dealt with the status before the treatment and follow-up after the treatment, it has been shown that the jitter values found within the normal limits but have been found to be higher than the baseline have not exceeded the normal limits during the follow-up. It has been reported that the average jitter has returned to normal in most patients after 3 months of follow-up (22). In our study, after the clinical effect of BtxA injection disappeared, we evaluated the ongoing effect at the neuromuscular junction with a cross-sectional analysis method. For this reason, we think that the jitter values we obtained within the normal limits can be interpreted similar to the findings in the literature.

\section{Study Limitations}

The fact that our study included relatively few patients constituted a limitation. Our study aimed to show ongoing effects during the period when the clinical effect of BtxA injection passed. Therefore, no prospective patient follow-up was conducted. Patients with pseudobotulsm or similar systemic adverse effects were not included in the study because there were no patients with pseudobotulism or similar systemic adverse effects followed up in our outpatient clinic. Our study was designed to look for subclinical neuromuscular function defects.

\section{Conclusion}

In our study, subclinical neuromuscular junction dysfunction was not detected in muscles without toxin injections during the period when the clinical effect of the toxin had passed in patients treated with botulinum toxin therapy. Therefore, it is important to keep in mind that neuromuscular junction dysfunction detected in distant muscles that have not been directly injected BtxA may be part of pseudobotulism.

\section{Ethics}

Ethics Committee Approval: This study was approved by the Ankara City Hospital's Ethics Committee 1 (number: E-19002).

Informed Consent: Written informed consent was obtained from all patients.

Peer-review: Internally peer-reviewed.

\section{Authorship Contributions}

Concept: N.Ö., Design: N.Ö., H.Ö.D., Data Collection or Processing: H.Ö.D., Y.S., Ş.B., Literature Search: H.Ö.D., Writing: H.Ö.D.
Conflict of Interest: No conflict of interest was declared by the authors.

Financial Disclosure: The authors declared that this study received no financial support.

\section{References}

1. Stalberg Erik TJ, Sanders Donald. Single Fiber EMG. Third ed. Fiskebackskil, Sweden: Edshagen Publishing House, 2010.

2. Lange F, van Weerden TW, van der Hoeven JH. Age-related botulinum toxin effects on muscle fiber conduction velocity in non-injected muscles. Clin Neurophysiol 2007;118:2398-2403.

3. Cote TR, Mohan AK, Polder JA, Walton MK, Braun MM. Botulinum toxin type A injections: adverse events reported to the US Food and Drug Administration in therapeutic and cosmetic cases. Journal of the American Academy of Dermatology 2005;53:407-415.

4. Ruet A, Durand MC, Denys P, et al. Single-fiber electromyography analysis of botulinum toxin diffusion in patients with fatigue and pseudobotulism. Arch Phys Med Rehabil 2015;96:1103-1109.

5. Baizabal-Carvallo JF, Jankovic J, Pappert E. Flu-like symptoms following botulinum toxin therapy. Toxicon 2011;58:1-7.

6. Glocker FX, Guschlbauer B, Lucking CH, Deuschl G. Effects of local injections of botulinum toxin on electrophysiological parameters in patients with hemifacial spasm: role of synaptic activity and size of motor units. Neurosci Lett 1995;187:161-164.

7. Sanders DB, Massey EW, Buckley EG. Botulinum toxin for blepharospasm: single-fiber EMG studies. Neurology 1986;36:545-547.

8. Lange DJ, Brin MF, Warner CL, Fahn S, Lovelace RE. Distant effects of local injection of botulinum toxin. Muscle Nerve 1987;10:552-555.

9. Hambleton P. Clostridium botulinum toxins: a general review of involvement in disease, structure, mode of action and preparation for clinical use. Journal of neurology 1992;239:16-20.

10. Ertas M, Baslo MB, Yildiz N, Yazici J, Oge AE. Concentric needle electrode for neuromuscular jitter analysis. Muscle Nerve 2000;23:715-719.

11. Stalberg E, Sanders DB, Kouyoumdjian JA. Pitfalls and errors in measuring jitter. Clin Neurophysiol 2017;128:2233-2241.

12. Sanders DB, Arimura K, Cui L, et al. Guidelines for single fiber EMG Clinical Neurophysiology 2019;130:1417-1439.

13. Stalberg E, Sanders DB, Ali S, et al. Reference values for jitter recorded by concentric needle electrodes in healthy controls: a multicenter study. Muscle Nerve 2016;53:351-362.

14. Naumann M, Jankovic J. Safety of botulinum toxin type A: a systematic review and meta-analysis. Curr Med Res Opi 2004;20:981-990.

15. Olney RK, Aminoff MJ, Gelb DJ, Lowenstein DH. Neuromuscular effects distant from the site of botulinum neurotoxin injection. Neurology 1988;38:1780-1783.

16. Antonucci F, Rossi C, Gianfranceschi L, Rossetto O, Caleo M. Long-distance retrograde effects of botulinum neurotoxin A. J Neurosci 2008;28:36893696.

17. Restani L, Antonucci F, Gianfranceschi L, et al. Evidence for anterograde transport and transcytosis of botulinum neurotoxin A (BoNT/A). J Neurosci 2011;31:15650-15659

18. Bakheit AM, Ward CD, McLellan DL. Generalised botulism-like syndrome after intramuscular injections of botulinum toxin type A: a report of two cases: J Neurol Neurosurg Psychiatry 1997;62:198.

19. Bhatia KP, Munchau A, Thompson PD, et al. Generalised muscular weakness after botulinum toxin injections for dystonia: a report of three cases. J Neurol Neurosurg Psychiatry 1999;67:90-93.

20. Garner CG, Straube A, Witt TN, Gasser T, Oertel WH. Time course of distant effects of local injections of botulinum toxin. Mov Disord 1993;8:3337.

21. Girlanda P, Vita G, Nicolosi C, Milone S, Messina C. Botulinum toxin therapy: distant effects on neuromuscular transmission and autonomic nervous system. J Neurol Neurosurg Psychiatry 1992;55:844-845.

22. Lange DJ, Rubin M, Greene PE, et al. Distant effects of locally injected botulinum toxin: a double-blind study of single fiber EMG changes. Muscle Nerve 1991;14:672-675 